\title{
A Comparison of Directed Reading Thinking Activity (DRTA) and Survey, Question, Read, Recite, and Reviews (SQ3R) Strategy to Improve Reading Comprehension Achievement of Indonesian Junior High School Students
}

\author{
Ara Bella Pandora Vista
}

Lampung University, Indonesia

\begin{abstract}
The objectives of the research were to investigate whether there was a statistically significant difference of the students' reading comprehension achievement after the implementation of DRTA strategy and SQ3R strategy. Furthermore, the approach used in this research was quantitative. The subjects were 32 students for DRTA group and 31 students for SQ3R group of Junior High school 9 Bandar Lampung. The reading tests were used as the research instrument. In addition, the data were analyzed by using Repeated Measure t-test. The result showed that there was a statically significant difference of students' reading comprehension with the significant level 0.05. From the result, it is suggested that SQ3R strategy can facilitate students better to improve their achievement in reading comprehension.
\end{abstract}

Keywords: reading comprehension, DRTA strategy, SQ3R strategy.

\section{INTRODUCTION}

Reading is the active process of understanding print and graphic texts. Effective readers know that when they read, what they read is supposed to make sense. Further, reading is an important part of the learning process since it is a basic component of learning. Reading is significant since it is a key process of learning new knowledge, according to Grabe and Stoller (2001). Furthermore, reading is frequently regarded as the most important of the four language skills that might improve students' academic knowledge. As a result, reading is always linked to academic achievement since the more students read, the more knowledge they learn.

Reading is one of the most important skills in learning English. It needs understanding of the meaning that is provided in the text. According to Harmer (1991), reading is an exercise dominated by the eyes and the brain. Specifically, Silberstein (1994) argues that the reading is an active process. The students work intensively and interactively with the text in order to create meaningful discourse.

Bernhardt (2011) describes that understanding reading is a process of extracting and constructing meaning simultaneously through contact and engagement with the written language in the text. This means the students must be able to grasp the concept in the text, which is often indirectly written.

Nevertheless, students often find have difficulty to read, it is one of the most significant problems that educators face today, according to Sadtono (1995), Retmono (1980) and Gunarwan (1988) (as cited in Sutarsyah 2015) identify that many school graduates or university students are poor readers of English texts, only small percentages of them can read fairly well. 
Ara Bella Pandora Vista. A comparison of directed reading thinking activity (DRTA) and survey, question, read, recite, and reviews (SQ3R) strategy to improve reading comprehension achievement of Indonesian junior high school students.

To improve the ability of learners to comprehend reading, teachers should be more conscious of their strategies and use in their teaching the most suitable strategy. Considering the conditions above, the writer is interested in applying Directed Reading Thinking Activity (DRTA) strategy to teach reading comprehension as the experiment class one and the writer also used Survey, Question, Read, Recite, and Review (SQ3R) as the experiment class two of this research.

Why the writer chose DRTA strategy as the experiment class, as it deliberately teaches comprehension skills to students. DRTA serves many purposes; to enable students to be involved and attentive readers, to activate students' prior knowledge, to allow students to track their comprehension of the text as they learn, and to help improve their ability to read and think critically. Tankersley (2005) states that the Directed Reading-Thinking Activities extend reading to higher-order thought processes and provides teachers with a great deal about each student's ideas, thought processes, prior knowledge and thinking skills.

A number of studies have been carried out on the application of DRTA. Some of these studies used DRTA with other strategies as combined reading strategies while some others used it as a single reading comprehension strategy. Yadzani and Mohammadi (2015), Aghdam and Behroozizad (2018), Chaemsai and Rattanavich (2016). The results of their research showed that DRTA strategies help the students to improve their ability to read.

Meanwhile, the other strategy to help students more comprehend in reading is SQ3R, which stands for "Survey, Question, Read, Recite and Review". The SQ3R strategy was found by Robinson in 1941. Robinson (1941) in Baier (2011), states that SQ3R is one of the reading strategies which provides students with a systematic approach presenting a detailed step by step outline of what readers should complete and accomplish while reading.
In the process of reading comprehension learning using SQ3R had 5 stages, namely survey, Question, Read, Recite, and reviews. Survey activities are carried out to get to know the concepts that will be studied by reviewing the reading titles, paragraphs, and forms of the discourse. Question has purpose to help students understand learning material by asking questions. Read is a reading activity to find the answers of student questions that are already in question stage, these questions are about reading topics, main ideas, explanatory sentences, and reading organizations. Recite is an activity to retell the contents of the reading with its own language. If students could retell the content of the reading properly, it means that they are successful. Review is a rereading activity with the aim of correcting errors. This SQ3R method is expected to overcome the problem of students' low reading comprehension ability.

\section{METHODS}

The approach of the research was quantitative. The design was one group pretest and post-test design. The population of the research was students of the second grade of SMP Negeri 9 Bandar Lampung and the sample of the research were class VIII B consisting of 32 students and VIII C consisting of 31 students. The activities were started from administering pre-test, doing treatment, and administering post-test.

The instruments used were reading comprehension tests. The reading test was administered twice: the first was pre-test and the second was post-test. Pre-test was conducted to know the students' reading comprehension ability before the treatment and post-test was given to know the students' reading comprehension ability after the treatment. The reading test consisted of 35 items in multiple choice. In analyzing the data, independent group t-test was used to prove the hypothesis and to know whether this research was significant or not by looking at the results of pre-test and post-test. 
Ara Bella Pandora Vista. A comparison of directed reading thinking activity (DRTA) and survey, question, read, recite, and reviews (SQ3R) strategy to improve reading comprehension achievement of Indonesian junior high school students.

\section{RESULTS AND DISCUSSION Results}

The pre-test was conducted to know the students' reading comprehension achievement before being taught by using DRTA and SQ3R strategy. This section elaborates the result of students' reading comprehension achievement of two classes, which included experimental class one and experimental class two. In the experimental class one student was taught through the DRTA strategy and in the experimental class two students were taught through SQ3R strategy. The following table was the comparison of the students' reading comprehension achievement in the pre-test.

Table 1. Comparison of the Students' Reading Comprehension Achievement in the Pre Test

\begin{tabular}{|l|l|l|l|l|l|}
\hline Descriptive Statistics & N & Minimum & Maximum & Mean & Std. Deviation \\
\hline DRTA strategy & 32 & 55 & 85 & 68.38 & 8.665 \\
\hline SQ3R strategy & 31 & 30 & 86 & 65.35 & 11.715 \\
\hline Valid N (listwise) & 31 & & & & \\
\hline
\end{tabular}

As shown in the table, there are 32 students in the experimental class one and 31 students in the experimental class two. Moreover, the mean score of the experimental class one is higher than the mean score of the experimental class two $(68.38<65.35)$. In addition, the minimum score of the experimental class one is 55 whereas the minimum score of the experimental class two is 30 . Besides, the maximum score of the experimental class one is 85 whereas the maximum score of the experimental class two is 86 . On the other hand, the mean of students' reading comprehension achievements in both classes were below the standard of minimum completeness of mastery learning for Junior High School 9 Bandar Lampung, which is 72. Thus, it indicated that the students' achievement in reading comprehension was still low.

After implementing the treatments of teaching reading comprehension through DRTA strategy and SQ3R strategy with a total of six meetings. It aimed to find out the students' reading comprehension achievement after the treatments were given. The following table was the comparison of the students' reading comprehension achievement in the post test of both classes.

Table 2. Comparison of the Students' Reading Comprehension Achievement in the Post Test

\begin{tabular}{|l|l|l|l|l|l|}
\hline \multicolumn{6}{|l|}{ Descriptive Statistics } \\
\hline & N & Minimum & Maximum & Mean & Std. Deviation \\
\hline DRTA strategy & 32 & 67 & 90 & 76.41 & 6.298 \\
\hline SQ3R strategy & 31 & 67 & 100 & 79.81 & 6.921 \\
\hline Valid N (listwise) & 31 & & & & \\
\hline
\end{tabular}

The mean score of the experimental class two is higher than the mean score of the experimental class one $(79.81<76.41)$. In addition, the minimum score of the experimental class one is 67 whereas the minimum score of the experimental class two is 67 . Besides, the maximum score of the experimental class one is 90 whereas the maximum score of the experimental class two is 100. On the other hand, some students' reading comprehension achievements in both groups were still below the standard of minimum completeness of mastery learning for Junior High School 9 Bandar Lampung, which is 72.

Furthermore, independent group ttest on SPSS version 17 was used to analyze the difference in reading comprehension achievement between students who are taught with DRTA strategy and SQ3R strategy. It is a statistical technique which is aimed to test the comparative hypothesis and to examine whether there is significant difference between the means of two groups which are independent. 
Ara Bella Pandora Vista. A comparison of directed reading thinking activity (DRTA) and survey, question, read, recite, and reviews (SQ3R) strategy to improve reading comprehension achievement of Indonesian junior high school students.

Table 3. Result of Independent Group T-test

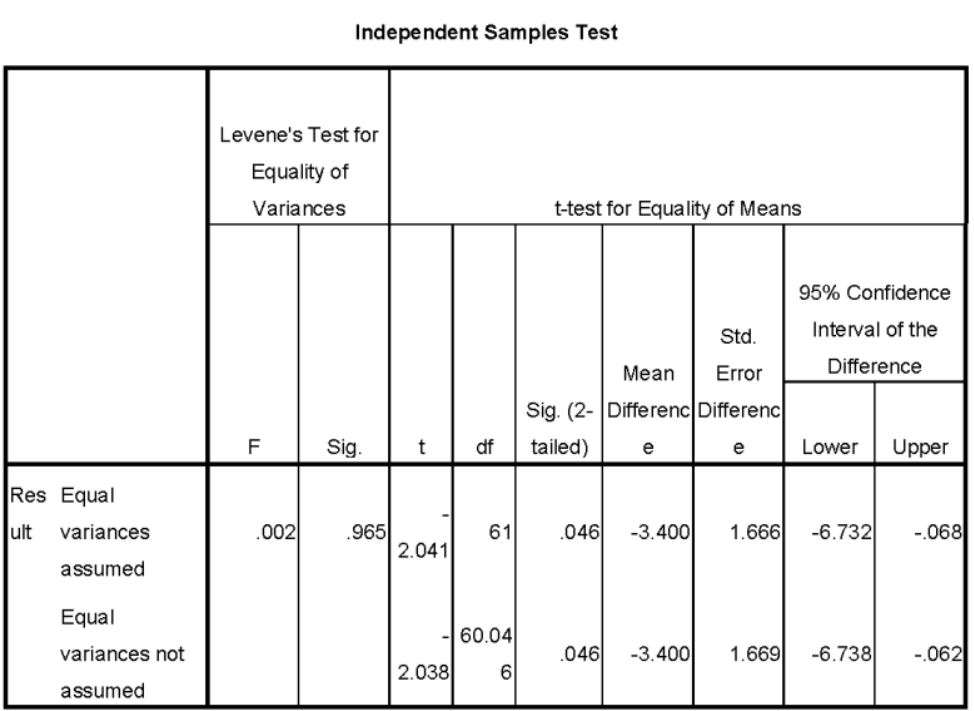

It can be seen from Table 3 the students' reading comprehension achievement shows a statistically significant difference between those taught with DRTA strategy and SQ3R strategy. It is revealed from t-value which is higher than t-table with the significance level of less than 0.05 $(2.038>2.003)(0.046<0.05)$. As a result, the hypothesis $\left(\mathrm{H}_{1}\right)$ is accepted and $\mathrm{H}_{0}$ is rejected.

\section{DISCUSSION}

Based on the analysis of an independent group t-test, there is a statistically significant difference in reading comprehension achievement between students who are taught with the DRTA strategy and those with the SQ3R strategy. In addition, there is improvement in students' reading comprehension achievement after the implementation of DRTA strategy and the SQ3R strategy. However, there is a difference in students' reading comprehension achievement from the two groups.

The researcher used online platforms such as Google Classroom, Google Forms, and WhatsApp to teach both classes. Because of the coronavirus, the researcher had to adapt to the situation. A coronavirus, or COVID-19, has been wreaking havoc on the world since the end of 2019. The virus was first found in the Chinese city of
Wuhan, in the province of Hubei. Until date, 95.124 people have been exposed to corona around the world (CNN, 2020). As a result of the COVID-19 pandemic, Indonesia's whole system, including government, economy, and education, has been disturbed. To break the chain of viruses, the president of the Republic of Indonesia approved a policy of temporarily suspending schools and colleges, encouraging students to study at home, and replacing them with online learning as of March 11, 2020

The first group of students, an experimental group one, was taught by using the DRTA strategy. There is a positive effect on students' reading comprehension achievement after the implementation of DRTA strategy. Yazdani and Mehdi (2015) argue that the directed reading thinking activity (DRTA) and guided reading (GR) indicate a positive influence on reading comprehension. There were two results of this study. Firstly, learning strategies could improve reading comprehension skills. Second, both strategies could improve the learners' reading comprehension skill however the directed reading thinking activity had a more significant positive effect than guided reading.

At the beginning, the students had difficulty in understanding the concepts and vocabularies in the text. Fortunately, at the 
Ara Bella Pandora Vista. A comparison of directed reading thinking activity (DRTA) and survey, question, read, recite, and reviews (SQ3R) strategy to improve reading comprehension achievement of Indonesian junior high school students.

end of the finding showed that students' reading comprehension achievement increased. DRTA provides meaningful steps that students are responsible for establishing their own purposes for reading, generating predictions, justifying those predictions, independently reading the text, and verifying or revising predictions based on evaluations of information in the text during the teacher-led discussion of each section which are that will make students become actively engaged in learning process.

According to the researchers' observations, the condition of reading activities in the experimental class one with the DRTA strategy made students more engaged in learning. Students create a positive motivation to comprehend reading material as a result of the processes in the DRTA strategy. Students are interested in asking questions and learning more about what they've read. At each treatment, the students' mastery of the material improves. According to Farida (2005) in Fitri (2019), the benefits of the DRTA strategy include: (a) a focus on student interaction with the text, because students predict and verify it while reading, and (b) encouraging students to use their metacognitive skills, because students think in their own way. The activity of understanding and predicting stories is a strength of this DRTA strategy since it helps students in comprehending the whole picture of what they have read and also piques their interest in learning, especially reading stories.

On the other hand, the second group of students, an experimental group two was treated by the researcher using SQ3R strategy. It can be seen that each step of SQ3R guided them in reading texts. In each meeting, except, firstly, the students did the first step, a survey. In this step, the students were asked to survey the clue using a picture of the text to get a general understanding of the text. The survey step, according to Tearney, Readence, and Dishner (1990), provides students with a general comprehension of the text material. The students were then instructed to fill out the survey column on their SQ3R worksheets in Google Form with what they knew about the text.

On the second step, question stage , the students were asked to write questions about the picture as a clue of the text and what they wanted to know about the person or place that was given in survey steps on the question column on their SQ3R worksheets. As stated by Robinson (1961) in Baier (2011), writing questions encourages students to look for answers to their questions. As a result, it will arouse readers' interest in the text, allowing them to have a better understanding of it (Robinson, 1961 in Baier, 2011). In addition, questioning allowed students to learn more about the material in depth. According to Tearney, Readence, and Dishner (1990), the students can learn more about the text in the question step.

On the third step, read, the students were asked to read the text to find the answers to their questions written in step 2 . As stated in Robinson (1961) in Baier, (2011); Tearney, Readence, \& Dishner (1990) the students read the text to find the answers to the questions created in step 2.

On the fourth step, recite, the students were asked to write their answers by their own words and a response about the text. According to Wright (2003), the recite step is restating the response before writing it. On the last step, review, the students were asked to reread the text to find the important information and the supporting details of the text. As stated in Wright (2003) the review step is reviewing the information and recalling the main points of the text and the supporting details. Then, they were given the task of writing a summary of the material. Summarizing is one of the activities in the activeness of a good reader (Ganske and Fisher, 2010). This last step of SQ3R makes students more comprehend with the text, because the students should rewrite or paraphrase with their own words. And this statement was support by Tearney, Readence, \& Dishner 
Ara Bella Pandora Vista. A comparison of directed reading thinking activity (DRTA) and survey, question, read, recite, and reviews (SQ3R) strategy to improve reading comprehension achievement of Indonesian junior high school students.

(2010) The last step of SQ3R is useful for long-term remembering

However, since the online learning situation, the researcher faces difficulties in ensuring that all students respond to teachers' questions related to the text given in both experimental classes.

Briefly, the research findings reveal that among two independent variables (SQ3R and DRTA) both of these strategies have a good effect on the students' reading comprehension. However, based on the analysis, described in the previous chapter, it can be concluded that the two strategies had produced improvement on students' reading comprehension.

\section{CONCLUSIONS AND SUGGESTIONS Conclusions}

There was a statistically significant difference between the students taught with the DRTA strategy and SQ3R strategy. It is revealed from $\mathrm{t}$-value which is higher than $\mathrm{t}-$ table with the significance level of less than 0.05. The implementation of the DRTA strategy and SQ3R strategy facilitate the students to be actively engaged in reading the text. Additionally, the steps of implementing DRTA consist of predicting, reading, and proving to help students in comprehending the reading passage. However, SQ3R have same steps in first stage but it had additional stage 'review' that make it the students' more comprehend with the text since they should rewrite or paraphrase the idea in the text. Thus, the SQ3R can improve students' reading comprehension achievement better than the DRTA strategy

\section{Suggestions}

Based on the conclusions above, the writer suggests that DRTA strategy and SQ3R strategy can be used as one of alternative strategies in teaching English spesifically to improve students' reading comprehension. In addition, English teachers should also consider the time allocation for applying those strategy in classroom since it has three meaningful steps which must be conducted well in order to achieve well-achievement.

\section{Acknowledgement: None}

\section{Conflict of Interest: None}

\section{Source of Funding: None}

\section{REFERENCES}

1. Aghdam, M.H \& Behroozizad, S. (2018). Directed Reading-Thinking Activity and Reading Comprehension. The Journal of English Language Pedagogy and Practice. Vol.11, No.22, pp.111-126, Spring \& Summer 2018.

2. Baier, K. (2011). The Effects of SQ3R on Fifth Grade Students' Comprehension Levels. Bowling Green State University.

3. Bernhardt, E.B. (2011). Understanding advanced second-language reading. New York: Routledge.

4. Chaemsai, R \& Rattanavich, S. (2016). The Directed Reading-Thinking Activity (DRTA) and the Traditional Approach Using Tales of Virtue based on His Majesty the King's Teaching Concepts in Seventh Grade Students' Reading Comprehension. Canadian Center of Science and Education. English Language Teaching; Vol. 9, No. 9; 2016

5. Fitri, R. (2019). The Effectiveness of Directed Reading Thinking Activity (DRTA) Strategy on upgrading the Reading comprehension skill of student in Primary School. 1st International Conference on Education, Social Sciences and Humanities (ICESSHum 2019).

6. Ganske, K., \& Fisher, D. (2010). Comprehension across the Curriculum: Perspective and Practices K-12. New York: The Guildford Press.

7. Grabe, W., \& Stoller, F. L. (2001). Reading for academic purposes: Guidelines for the ESL/EFL teacher. In M. Celce-Murcia (Ed.), Teaching English as a second or foreign language (3rd ed.) (pp.187-203). Boston, MA: Heinle \& Heinle

8. Harmer, J. (1991). The Practice of English Language Teaching: Third Edition. New York: Longman Publishing.

9. Silberstein, S. (1994). Techniques and Resources in teaching reading. Oxford University Press. 
Ara Bella Pandora Vista. A comparison of directed reading thinking activity (DRTA) and survey, question, read, recite, and reviews (SQ3R) strategy to improve reading comprehension achievement of Indonesian junior high school students.

10. Sutarsyah, C. (2015). Reading theories and practice. Yogyakarta: Graha Ilmu.

11. Tankersley, K. (2005). Literacy Strategies for Grades 4-12: Reinforcing the Threads of Reading. Alexandria, VA: Association for Supervision and Curriculum Development.

12. Tearney, Robert. J., Readence, John. \& Dishner, E. (1990). Reading Strategies and Practices: A Compendium. US: Allyn and Bacon.

13. Yazdani, M.M., \& Mohammadi, M. (2015). The Explicit Instruction of Reading Strategies: Directed Reading Thinking Activity vs. Guided Reading Strategies. International Journal of Applied Linguistics \& English Literature. Vol 4. No 3, May 2015.
14. Wright, D. B. (2003). SQ3R Reading Strategy. Retrieved on August 24, 2021 from

15. http://blogs.academyart.edu/dam/highschool-diplomaprogram/assets/SQ3Rmethodofstudy.pdf

How to cite this article: Vista ABP. A comparison of directed reading thinking activity (DRTA) and survey, question, read, recite, and reviews (SQ3R) strategy to improve reading comprehension achievement of Indonesian junior high school students. International Journal of Research and Review. 2021; 8(8): 689-695. DOI: https://doi.org/10.52403/ijrr. 20210891 